Article

\title{
DBU Catalyzed Phospho-Aldol-Brook Rearrangement for Rapid Preparation of $\alpha$-Phosphates Amide in Solvent-Free Conditions
}

\author{
Shunhong Chen ${ }^{\dagger}$, Shengxin Guo ${ }^{\dagger}$, Feng He, Yingxia Zhang, Zengxue Wu and Jian Wu *(D) \\ State Key Laboratory Breeding Base of Green Pesticide and Agricultural Bioengineering, Key Laboratory of \\ Green Pesticide and Agricultural Bioengineering, Ministry of Education, Guizhou University, Huaxi District, \\ Guiyang 550025, China; csh2018jhzx@163.com (S.C.); guoshengxin97321@163.com (S.G.); \\ hefeng121511@163.com (F.H.); zhangyinxia@163.com (Y.Z.); WZX3120@163.com (Z.W.) \\ * Correspondence: jwu6@gzu.edu.cn; Tel.: +86-851-88292090 \\ † Equal contribution to this manuscript.
}

Received: 7 November 2020; Accepted: 5 December 2020; Published: 10 December 2020

check for updates

\begin{abstract}
The 1,8-diazabicyclo [5.4.0] undec-7-ene DBU-catalyzed Phospho-Aldol-Brook Rearrangement reaction of $\alpha$-ketoamide and dialkyl phosphites was developed under solvent-free at room temperature. The novel $\alpha$-Phosphate Amide derivatives could be obtained with good yield (86-96\%), which also exhibited good tolerance of various dialkyl phosphites and $\alpha$-ketoamide, including isatins. In addition, the reaction was conducted in both gram-scale and mol-scale, and the title compounds could also be obtained in excellent yield (more than 91\%) within 5 min.
\end{abstract}

Keywords: solvent-free; Phospho-Aldol-Brook Rearrangement; $\alpha$-Phosphates Amide; gram/mol-scale synthesis; DBU

\section{Introduction}

Organophosphorus compounds (OPs) play an important role in the pesticides industry and drug discovery; their preparation and application have attracted increasing attention [1,2]. Phosphates are a type of organophosphorous and play a unique part in drug design due to their broad spectrum of biological activities and versatility in chemistry synthesis [3-10]. An increasing number of approaches for the synthesis of phosphates derivatives have been reported recently [11-15]. For example, along with the formation of C-P bone between different carbonyl and dialkyl phosphites (Pudovik reaction) or trialkyl phosphites (Abramov reaction), $\alpha$-hydroxyphosphates could be widely synthesized and used as agrochemical [16-18] or medical agents $[19,20]$. Moreover, some literature proposes that $\alpha$-hydroxyphosphates could be transformed to phosphate derivatives via the Phospho-Aldol-Brook Rearrangement in the presence of specific base [21-24]. For instance, Nakamura and coworkers reported the preparation of $\alpha$-phosphonyloxy esters by the reaction of $\alpha$-ketoesters with phosphates by using cinchona alkaloids and $\mathrm{Na}_{2} \mathrm{CO}_{3}$ as catalysts in the solvent of cyclopentyl methyl ether (Figure 1) [25]. More recently, a large number of catalysts have been used to catalyze the Phospho-Aldol-Brook Rearrangement smoothly, such as strong Brønsted base [26], $\mathrm{NEt}_{3}$ [27,28], $\mathrm{NaH}$ [28], n-butylamine [29], $\mathrm{K}_{2} \mathrm{CO}_{3} / \mathrm{KOH}$ [30], NaOEt [31], and t-BuOK [32,33]. Many of the strategies have been studied to synthesize novel phosphates effectively through Phospho-Aldol-Brook Rearrangement. However, the majority of these catalysts are also associated with harsh reaction conditions, such as high temperature, high pressure or toxic regents as solvent, long reaction time and lower product yield. Hence, development of an eco-friendly and economical strategy with high efficiency to prepare novel phosphates is still desirable and in demand. 
(a)

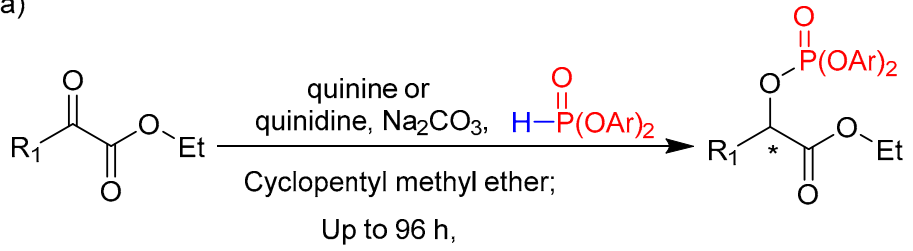

(b)

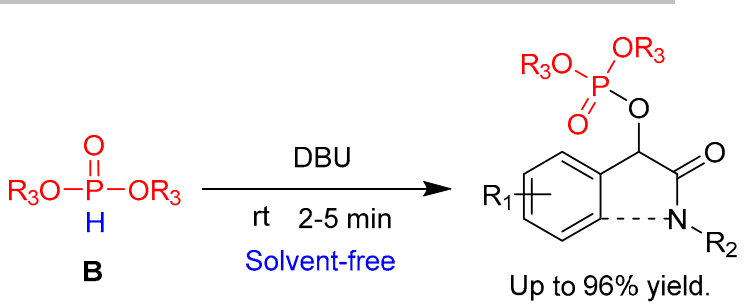

Figure 1. The synthesis of novel phosphates derivatives via Phospho-Aldol-Brook Rearrangement. (a) Nakamura's work [25]; (b). This work.

In organic synthesis, most of the organic reactions require solvents as the medium. These solvents are usually volatile organic compounds and unsafe for both human beings and the environment [34]. In contrast, the removal of solvents from chemical reactions generally leads to cleaner, more efficient and more economical processes [35]. Consequently, solvent-free protocols have become increasingly prevalent in recent years [34-36]. Furthermore, solvent-free conditions are considered to be a favored sustainable method owing to the low energy consumption and expedited transformations in a short reaction time [36].

In this work, we performed a rapid protocol for synthesis of $\alpha$-Phosphates Amides under solvent-free conditions. Desirably, $\alpha$-Phosphate Amide derivatives could be easily obtained in excellent yields through the reaction of $\alpha$-ketoamides with dialkyl phosphites within 5 min using 1,8-diazabicyclo [5.4.0] undec-7-ene (DBU) for solvent-free catalysis (Figure 1). To our best knowledge, this is the first time that $\alpha$-Phosphates Amides derivatives could be obtained using DBU as a catalyst in solvent-free conditions.

\section{Results}

Based on our previous work [37], $\alpha$-ketoamides (substrate A), was firstly prepared. Applying the reaction of $N$-cyclohexyl-2-oxo-2-phenylacetamide (A) and diethyl phosphite (B), a model reaction was constructed to screen the best reaction conditions, including the reaction time, solvent, catalyst and temperature, which are shown in Table 1 . Several organic solvents including $\mathrm{EtOH}, \mathrm{CH}_{2} \mathrm{Cl}_{2}$ and THF were firstly investigated; the yields of products were $81 \%, 83 \%$ and $89 \%$, respectively (Table 1 , entries 1-3). We also investigated the effect of water on this reaction. Unfortunately, only a trace product of the model was provided in water (Table 1, entry 4). Surprisingly, we found that the reaction could be conducted smoothly $(92 \%$ yield) in resent DBU $(\mathrm{pKb}=2)$ in solvent-free conditions (Table 1 , entry 5). In order to screen more suitable alkali, different alkalis including 4-dimethylaminopyridine (DMAP, $\mathrm{pKb}=4.8$ ), triethylamine (TEA, $\mathrm{pKb}=4.25), \mathrm{K}_{2} \mathrm{CO}_{3}, \mathrm{NaOH}$ were then investigated (Table 1, entries 6-10). Unfortunately, the inorganic alkalis $\left(\mathrm{NaOH}\right.$ or $\left.\mathrm{K}_{2} \mathrm{CO}_{3}\right)$ shewed low catalytic capability due to low solubility in dialkyl phosphite (Table 1, entries 6, 7). Under the same conditions (solvent-free, $50{ }^{\circ} \mathrm{C}, 60 \mathrm{~min}$ ), the reaction catalyzed by TEA could provide $5 \%$ yield of the product (Table 1 , entry 8 ). Desirably, the yield could be enhanced (yield, 78\%) by using $10 \mathrm{~mol} \%$ DMAP at room temperature (rt) within 5 min (Table 1, entry 9). However, the yield (up to 92\%) could be improved by DBU (Table 1, entry 10). For these three organic alkalis, both DMAP and DBU show better nucleophilicity than that of TEA. In addition, DBU shows much stronger alkalinity than DMAP and better capability to capture the proton from dialkyl phosphite than that of DMAP. Hence, the catalytic capability of DBU is the best one in these alkalis. Moreover, the reaction time, amount of DBU, and the reaction temperature were also investigated. Higher reaction time (Table 1, entries 11 and 13), higher temperature (Table 1, 
entries 13 and 15) and more dosage of DBU (20 mol\%, entry 12) could not clearly increase the yield of products. However, the yield of the product was sharply reduced by decreasing the amount of DBU (Table 1, entry 14). Hence, the optimized reaction conditions for the preparation of $\alpha$-Phosphates Amide could be concluded as follows: solvent-free, $10 \mathrm{~mol} \%$ DBU as catalyst, and room temperature.

Table 1. Optimization for the reaction conditions (model reaction).

\begin{tabular}{cccccc}
\hline & & & & & \\
\hline
\end{tabular}

Letters a-d represent the amount of catalyst is $10 \mathrm{~mol} \%, 15 \mathrm{~mol} \%, 20 \mathrm{~mol} \%, 5 \mathrm{~mol} \%$, and, respectively.

Having established the optimized conditions, an exploration of the scope of substrates A and B was carried out using various $\alpha$-ketoamides and dialkyl phosphites, which are summarized in Table 2. When $R_{2}$ and $R_{3}$ were tert-butyl and ethyl respectively, the yields of products are also over $90 \%$ (Table 2, entries 12-14). Specifically, the position of methyl on benzene slightly affected the yields of products (Table 2, entries 13,14 ). When $R_{2}$ and $R_{3}$ are cyclohexyl and methyl, respectively, the yields of products varied from $89 \%$ to $95 \%$ (Table 2, entries $15-19$ ). When $\mathrm{R}_{1}$ is 2 -nitro or 3-methoxy, the yields of products are all $89 \%$ (Table 2, entries 18, 19), which are slightly lower than that of hydrogen, 3-methyl and 4-bromine (Table 2, entries 15-17). When $R_{2}$ and $R_{3}$ are confirmed to be tert-butyl and methyl, respectively, methyl substituting at different position of benzene could provide yields of 91\% (Table 2, entries 21, 22). 3-Chlorine substituting in benzene could slightly decrease the yields of products from $93 \%$ to $90 \%$ (Table 2, entries 20, 23). Moreover, when $R_{2}$ and $R_{3}$ are confirmed to be cyclohexyl and isopropyl respectively, the yields of products vary from $88 \%$ to $91 \%$ (Table 2, entries 24-28). Among them, the 3-methyl substituting in benzene ring could provide slightly lower yield of $88 \%$ than other substituent (Table 2, entry 26). When $R_{2}$ and $R_{3}$ are tert-butyl and isopropyl respectively, non-substituent and methyl substituting in benzene ring provided the yields of $92 \%$ and $91 \%$, respectively (Table 2 , entries 29,30 ). When $R_{2}$ and $R_{3}$ are cyclohexyl and isobutyl respectively, the yields are all less than $90 \%$ (Table 2, entries 31-34). Among them, 3-methoxyl substituting in the benzene ring obtained the lowest yield of $86 \%$ (Table 2, entry 33). When $R_{2}$ and $R_{3}$ are tert-butyl and isobutyl respectively, four substituents all provided the same yield of $90 \%$ (Table 2, entries 35-38). Undesirably, when the substrate B is diphenyl phosphonate, only trace product could be obtained because of the steric effect [38] (Table 2, entry 39). Generally, as shown in Table 2, the proposed strategy in this work could be well tolerated with different $\alpha$-ketoamides and dialkyl phosphites. The physicochemical properties, NMR data and spectra for these compounds can be found in Supplementary Materials. 
Table 2. The synthesis of a series of $\alpha$-Phosphate Amide derivatives a

\begin{tabular}{|c|c|c|c|c|c|c|}
\hline Entry & $\begin{array}{l}\text { Compound } \\
\text { Number }\end{array}$ & $\mathbf{R}_{1}$ & $\mathbf{R}_{\mathbf{2}}$ & $\mathbf{R}_{3}$ & $\begin{array}{c}\text { Yield } \\
(\%)\end{array}$ & m.p $\left({ }^{\circ} \mathrm{C}\right)$ \\
\hline 1 & $\mathrm{C}_{1}$ & $\mathrm{H}$ & $0^{\frac{\pi}{2}}$ & Et & 92 & $55-56$ \\
\hline 2 & $\mathrm{C}_{2}$ & 2- $\mathrm{Cl}$ & $\sigma^{\frac{\pi}{2}}$ & $\mathrm{Et}$ & 92 & 79-80 \\
\hline 3 & $\mathrm{C}_{3}$ & 4- $\mathrm{Cl}$ & $0^{\frac{1}{2}}$ & $\mathrm{Et}$ & 92 & $79-80$ \\
\hline 4 & $\mathrm{C}_{4}$ & 2- $\mathrm{Br}$ & $\sigma^{\frac{\pi}{2}}$ & Et & 91 & $80-81$ \\
\hline 5 & $\mathrm{C}_{5}$ & 3- $\mathrm{Br}$ & $\sigma^{\frac{k}{2}}$ & $\mathrm{Et}$ & 91 & 84-85 \\
\hline 6 & $\mathrm{C}_{6}$ & 4- F & $\sigma^{\frac{1}{2}}$ & $\mathrm{Et}$ & 89 & $72-73$ \\
\hline 7 & $C_{7}$ & 3- $\mathrm{CH}_{3}$ & $\sigma^{\frac{1}{2}}$ & $\mathrm{Et}$ & 91 & $55-57$ \\
\hline 8 & $\mathrm{C}_{8}$ & 4- $\mathrm{CH}_{3}$ & $0^{\frac{r}{2}}$ & Et & 91 & $73-74$ \\
\hline 9 & $\mathrm{C}_{9}$ & 3- $\mathrm{NO}_{2}$ & $0^{\frac{r}{2}}$ & Et & 92 & $81-82$ \\
\hline 10 & $\mathrm{C}_{10}$ & $4-\mathrm{NO}_{2}$ & $0^{\frac{r}{2}}$ & $\mathrm{Et}$ & 90 & $90-92$ \\
\hline 11 & $\mathrm{C}_{11}$ & 3- $\mathrm{OCH}_{3}$ & $O^{\frac{1}{2}}$ & $\mathrm{Et}$ & 90 & $80-82$ \\
\hline 12 & $\mathrm{C}_{12}$ & $\mathrm{H}$ & $\xi$ & $\mathrm{Et}$ & 92 & $62-64$ \\
\hline 13 & $\mathrm{C}_{13}$ & 3- $\mathrm{CH}_{3}$ & $\xi$ & $\mathrm{Et}$ & 90 & $58-60$ \\
\hline 14 & $\mathrm{C}_{14}$ & 4- $\mathrm{CH}_{3}$ & $\xi$ & $\mathrm{Et}$ & 92 & $51-52$ \\
\hline 15 & $\mathrm{C}_{15}$ & $\mathrm{H}$ & $\sigma^{\frac{1}{2}}$ & $\mathrm{Me}$ & 95 & $70-72$ \\
\hline 16 & $\mathrm{C}_{16}$ & 3- $\mathrm{CH}_{3}$ & $y_{\frac{1}{2}}$ & $\mathrm{Me}$ & 93 & $72-73$ \\
\hline 17 & $\mathrm{C}_{17}$ & $4-\mathrm{Br}$ & $\sigma^{\frac{1}{2}}$ & $\mathrm{Me}$ & 91 & $100-101$ \\
\hline 18 & $\mathrm{C}_{18}$ & 2- $\mathrm{NO}_{2}$ & $\mathrm{O}^{\frac{1}{2}}$ & $\mathrm{Me}$ & 89 & $97-98$ \\
\hline 19 & $\mathrm{C}_{19}$ & 3- $\mathrm{OCH}_{3}$ & $\frac{1}{2}$ & $\mathrm{Me}$ & 89 & $78-80$ \\
\hline 20 & $\mathrm{C}_{20}$ & $\mathrm{H}$ & $\xi$ & $\mathrm{Me}$ & 93 & $75-76$ \\
\hline 21 & $\mathrm{C}_{21}$ & 3- $\mathrm{CH}_{3}$ & $\xi$ & $\mathrm{Me}$ & 91 & $67-69$ \\
\hline 22 & $\mathrm{C}_{22}$ & 4- $\mathrm{CH}_{3}$ & $\xi$ & $\mathrm{Me}$ & 91 & $68-69$ \\
\hline
\end{tabular}


Table 2. Cont.

\begin{tabular}{|c|c|c|c|c|c|c|}
\hline Entry & $\begin{array}{l}\text { Compound } \\
\text { Number }\end{array}$ & $\mathbf{R}_{\mathbf{1}}$ & $\mathbf{R}_{2}$ & $\mathbf{R}_{3}$ & $\begin{array}{c}\text { Yield } \\
(\%)\end{array}$ & m.p $\left({ }^{\circ} \mathrm{C}\right)$ \\
\hline 23 & $\mathrm{C}_{23}$ & 3- $\mathrm{Cl}$ & $\xi$ & $\mathrm{Me}$ & 90 & $81-83$ \\
\hline 24 & $\mathrm{C}_{24}$ & $\mathrm{H}$ & & $i-\operatorname{Pr}$ & 91 & $76-77$ \\
\hline 25 & $\mathrm{C}_{25}$ & $2-\mathrm{OCH}_{3}$ & & $i-\operatorname{Pr}$ & 89 & $76-78$ \\
\hline 26 & $\mathrm{C}_{26}$ & 3- $\mathrm{OCH}_{3}$ & & $i-\operatorname{Pr}$ & 88 & $79-80$ \\
\hline 27 & $\mathrm{C}_{27}$ & 4- F & & $i-\operatorname{Pr}$ & 90 & $84-85$ \\
\hline 28 & $\mathrm{C}_{28}$ & 4- $\mathrm{Br}$ & & $i-\operatorname{Pr}$ & 89 & $96-97$ \\
\hline 29 & $\mathrm{C}_{29}$ & $\mathrm{H}$ & $<$ & $i-\operatorname{Pr}$ & 92 & $67-68$ \\
\hline 30 & $\mathrm{C}_{30}$ & 4- $\mathrm{CH}_{3}$ & $k$ & $i-\operatorname{Pr}$ & 91 & $70-72$ \\
\hline 31 & $\mathrm{C}_{31}$ & $\mathrm{H}$ & & $i-\mathrm{Bu}$ & 88 & $71-73$ \\
\hline 32 & $\mathrm{C}_{32}$ & $2-\mathrm{OCH}_{3}$ & & $i$-Bu & 87 & $75-77$ \\
\hline 33 & $\mathrm{C}_{33}$ & 3- $\mathrm{OCH}_{3}$ & & $i-\mathrm{Bu}$ & 86 & $81-82$ \\
\hline 34 & $\mathrm{C}_{34}$ & $4-\mathrm{NO}_{2}$ & & $i-\mathrm{Bu}$ & 88 & 98-100 \\
\hline 35 & $\mathrm{C}_{35}$ & $\mathrm{H}$ & K & $i-\mathrm{Bu}$ & 90 & $68-70$ \\
\hline 36 & $\mathrm{C}_{36}$ & 3- $\mathrm{Cl}$ & $\xi$ & $i-\mathrm{Bu}$ & 90 & $74-76$ \\
\hline 37 & $\mathrm{C}_{37}$ & 4- $\mathrm{Cl}$ & $\xi<$ & $i-\mathrm{Bu}$ & 90 & $82-84$ \\
\hline 38 & $\mathrm{C}_{38}$ & 4- $\mathrm{CH}_{3}$ & $\xi<$ & $i-\mathrm{Bu}$ & 90 & $75-77$ \\
\hline 39 & $\mathrm{C}_{39}$ & $\mathrm{H}$ & & $\mathrm{Ph}$ & trace & - \\
\hline
\end{tabular}

a Catalyzed by DBU $(0.1 \mathrm{mmol})$, all reactions, were carried out between $\alpha$-ketone amide $(1 \mathrm{mmol})$ with various phosphites ester $(1 \mathrm{mmol})$ in the absence of solvent at rt within $5 \mathrm{~min}$.

The scope of substrate A was further investigated for the proposed strategy considering the rich biological activities of isatin-based derivatives [39-42]. Provirus work reported that the Phospho-Aldol-Brook Rearrangement reaction could conduct between isatin and dialkyl phosphite in THF [43]. Various substituted isatins were chosen as substrate A for the Phospho-Aldol-Brook Rearrangement reaction under solvent-free conditions. As shown in Table 3, the proposed strategy owned a broad substrate scope for the preparation of $\alpha$-Phosphate Amide derivatives via Phospho-Aldol-Brook Rearrangement, the reactions could proceed quite well from the materials of isatins (substrate A) and various dialkyl phosphites (substrate B) under the optimized conditions, which could provide yields beyond $93 \%$ (Table 3). Particularly, when $R_{2}$ and $R_{3}$ are hydrogen and methyl respectively, the yields (Table 3, entries 1,4 ) could be enhanced by hydrogen or 5 -methyl (refer to $R_{1}$ ) and up to $96 \%$. More details for the physicochemical properties and NMR spectra of these compounds are also shown in Supplementary Materials. 
Table 3. The synthesis of isatin-based $\alpha$-Phosphate Amide derivatives ${ }^{b}$.

\begin{tabular}{|c|c|c|c|c|c|}
\hline \multirow[b]{2}{*}{ Entry } & \multirow[b]{2}{*}{$\mathbf{R}_{\mathbf{1}}$} & \multirow{2}{*}{$\frac{\mathbf{R}_{2}}{\mathbf{R}_{3}}$} & \multicolumn{2}{|c|}{$\underset{\substack{\mathrm{rt} \\
\text { Solvent-free }}}{\stackrel{\mathrm{DBU}}{\longrightarrow}}$} & \multirow{2}{*}{$\mathrm{m} \cdot \mathrm{p}\left({ }^{\circ} \mathrm{C}\right)$} \\
\hline & & & $\mathbf{R}_{3}$ & Yield (\%) & \\
\hline 1 & $\mathrm{H}$ & $\mathrm{H}$ & $\mathrm{Me}$ & 96 & $95-96$ \\
\hline 2 & $4-\mathrm{Br}$ & $\mathrm{H}$ & Et & 95 & 132-133 \\
\hline 3 & $5-\mathrm{Cl}$ & $\mathrm{H}$ & $\mathrm{Me}$ & 95 & 117-118 \\
\hline 4 & 5-Me & $\mathrm{H}$ & $\mathrm{Me}$ & 96 & $116-117$ \\
\hline 5 & $5-\mathrm{NO}_{2}$ & $\mathrm{H}$ & Et & 94 & 159-160 \\
\hline 6 & $7-\mathrm{Br}$ & $\mathrm{H}$ & $\mathrm{Me}$ & 95 & $157-159$ \\
\hline 7 & $5,7-\left(\mathrm{CH}_{3}\right)_{2}$ & $\mathrm{H}$ & Et & 93 & 147-148 \\
\hline 8 & 7-Me & $\mathrm{H}$ & Ipr & 94 & $112-114$ \\
\hline
\end{tabular}

b All reactions were carried out between isatin $(1 \mathrm{mmol})$ with various dialkyl phosphites $(1 \mathrm{mmol})$ catalyzed by DBU $(0.1 \mathrm{mmol})$ in the absence of solvent at rt within $2 \mathrm{~min}$.

Based on the reported literatures $[22,25,26]$, a plausible mechanism of the reaction is predicted as Scheme 1. At first, and triggered by DBU, a rapid deprotonation of dialkyl phosphites (A) was carried out, releasing an intermediate 2 to generate intermediate 1 . The intermediate 1 then attack the carbonyl carbon of $\alpha$-ketoamide (substrate B) to give alkoxide 3 [26]. Subsequently, the 1,2-rearrangement of the dialkylphosphono group from carbon to oxygen yields intermediate 4. Finally, protonation of intermediate 4 by the conjugated acid 2 of the DBU proceeds to afford final product and DBU for next circle [26].

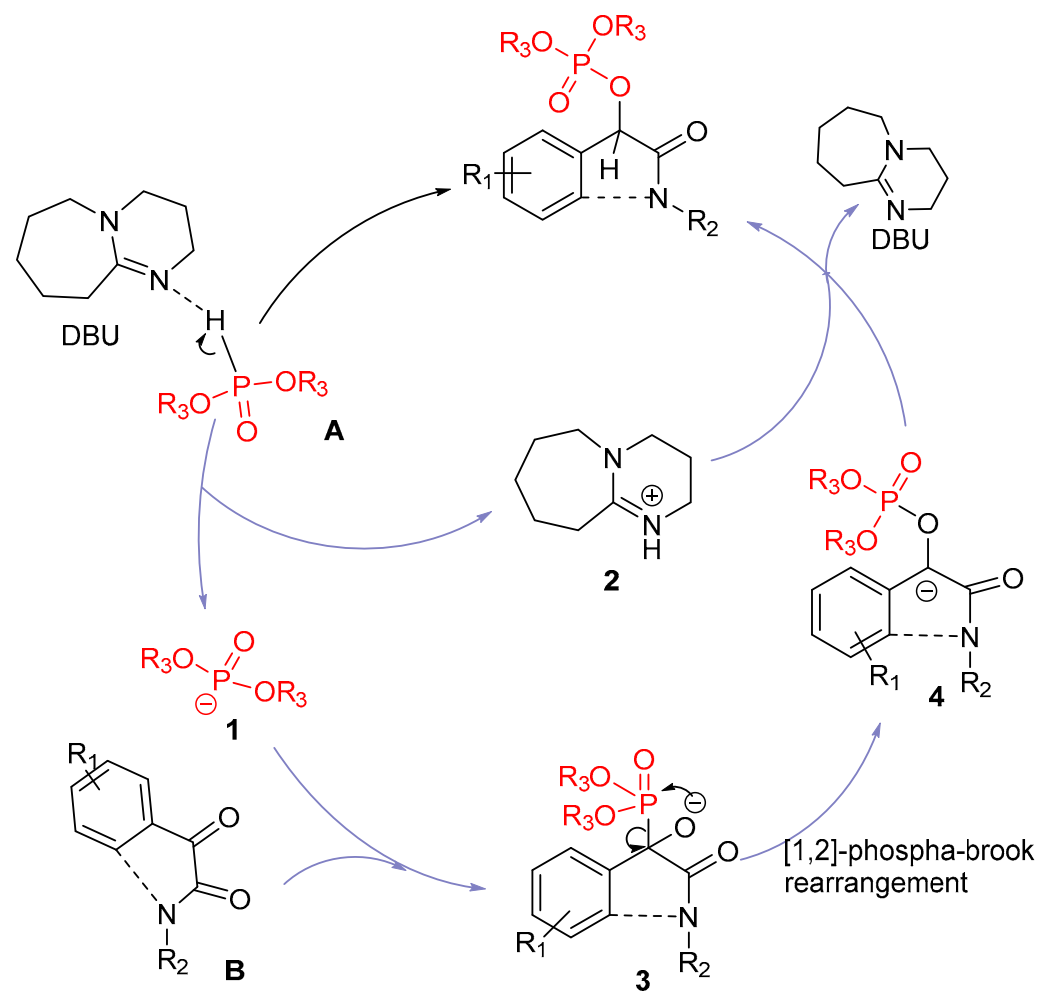

Scheme 1. Possible mechanism for the preparation of novel $\alpha$-Phosphate Amide derivatives via Phospha-Brook Rearrangement. 
To investigate the rearrangement under the solvent-free conditions, a gram-scale (Scheme 2a) and mol-scale (Scheme $2 b$ ) synthesis were randomly selected to indicate the feasibility of this strategy on a preparative scale. The result indicated the reactions could be conducted smoothly in both gram-scale and mol-scale. The yields of the selected reactions were more than $91 \%$.

(a)<smiles>Cc1ccc2c(c1)C(=O)C(=O)N2</smiles><smiles>CO[PH](=O)OC</smiles>

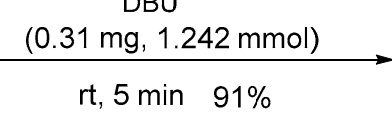

(1.37g, $12.41 \mathrm{mmol})$

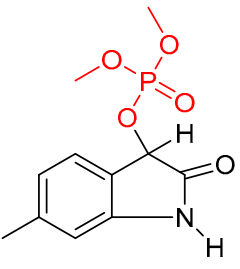

$3.06 \mathrm{~g}$

(b)<smiles>O=C1Nc2ccccc2C1=O</smiles>

(270 g, $1.83 \mathrm{~mol})$<smiles>CO[PH](=O)OC</smiles>

$(202 \mathrm{~g}, 1.83 \mathrm{~mol})$
DBU

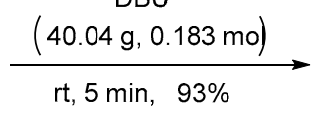

rt, $5 \mathrm{~min}, \quad 93 \%$

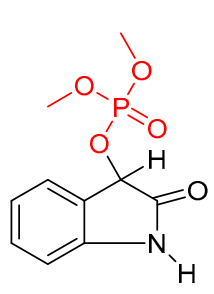

$439.3 \mathrm{~g}$

Scheme 2. Preparative scale synthesis of $\alpha$-Phosphate Amide under optimized reaction conditions, (a) Gram-scale synthesis of $\alpha$-Phosphate Amide under optimized reaction conditions; (b) Mol-scale synthesis of $\alpha$-phosphate amide under optimized reaction conditions.

\section{Materials and Methods}

\subsection{Materials and Methods}

Unless otherwise stated, all the reagents and reactants were purchased from commercial suppliers, and used without further purification. Melting points (uncorrected) were determined on a XT-4 binocular microscope (Beijing Tech Instrument Co, Beijing, China). The ${ }^{1} \mathrm{H}-\mathrm{NMR},{ }^{13} \mathrm{C}-\mathrm{NMR}$ and ${ }^{31}$ P-NMR spectra were recorded on a J Agilent 6890/5973 Inert (Agilent corporation, Palo Alto, USA) at room temperature operating on an AVANCE III HD 400M NMR (Bruker Corporation, Fällanden, Switzerland) using $\mathrm{CDCl}_{3}$ as solvents and TMS as an internal standard. Detection of High-resolution mass spectra (HRMS) was recorded by Orbitrap LC-MS instrument (Q-Exative, Thermo Scientific ${ }^{\mathrm{TM}}$, Waltham, USA). The course of the reactions was monitored by TLC. Analytical TLC was performed on silica gel GF 254.

\subsection{Preparation of $C_{1}$ and $C_{46}$}

Under solvent-free conditions, the $\alpha$-ketonamide $(0.65 \mathrm{mmol})$ and dialkyl phosphites $(0.65 \mathrm{mmol})$ were added in one portion, which was stirred at room temperature. The reaction was monitored and completed within 5 min to provide crude products, which were purified by silica gel (200-300 mesh) column chromatography with using ethyl acetate/petroleum ether (1:3).

\section{Conclusions}

For the small scale Phospho-Aldol-Brook Rearrangement reaction, 1 mmol equivalent of 5-methylindoline-2, 3-dione and $1 \mathrm{mmol}$ equivalent of dialkyl phosphites were required with the yield of $96 \%$. Fortunately, the reaction was conducted in both gram-scale and mol-scale, and the title compounds could be obtained in excellent yield (more than 91\%) within 5 min. 
Herein, based on a quality of experiments, a facile strategy was successfully proposed to obtain a series of novel $\alpha$-Phosphate Amide derivatives from various substituted $\alpha$-ketoamide, including isatins and various dialkyl phosphites. Owing the characters of a low amount of metal-free catalyst $(10 \mathrm{~mol} \%)$, solvent-free, broaden scope of substrates (A and B), short reaction time (within $5 \mathrm{~min}$ ), high yields $(86-96 \%)$, high purity and mild reaction condition (rt), the current work provides a more environmentally friendly and economically available strategy for the green synthesis of $\alpha$-Phosphate Amide derivatives.

Supplementary Materials: The following are available online at http://www.mdpi.com/2073-4344/10/12/1445/s1, Materials information, experiment, the spectral data of title compounds, and the NMR spectra of products.

Author Contributions: S.C., contributed to the experiment and characterization. S.G., contributed to the drafting of the manuscript. F.H., Y.Z., and Z.W. Assisted S.C. to carry out relevant experiments. J.W., provided scientific guidance, supervision, visualization, project administration, funding acquisition. All authors have read and agreed to the published version of the manuscript.

Funding: This work was supported by the National Natural Science Foundation of China (Nos. 21762012), Program of Introducing Talents to Chinese Universities (111 Program, D20023), and the S \&T Planning Project of Guizhou Province (Nos. [2017] 1402, [2017] 5788).

Conflicts of Interest: The authors declare no conflict of interest.

\section{References}

1. Savignac, P.; Iorga, B. Modern Phosphonates Chemistry; CRC: New York, NY, USA, 2003.

2. Murphy, P.J. Organophosphorus Reagents; Oxford University Press: Oxford, UK, 2004.

3. Chen, L.J.; Guo, T.; Xia, R.J.; Tang, X.; Chen, Y.; Zhang, C. Novel Phosphorylated Penta-1,4-dien-3-one Derivatives: Design, Synthesis, and Biological Activity. Molecules 2019, 24, 925. [CrossRef] [PubMed]

4. Abd El-Wahab, Z.H.; El-Sarrag, M.R. Derivatives of phosphate Schiff base transition metal complexes: Synthesis, studies and biological activity. Spectrochim. Acta Part A 2004, 60, 271-277. [CrossRef]

5. Kalinowska-Lis, U.K.; Szewczyk, E.M.; Wojciechowski, J.M.; Chęcińska, L.; Wojciechowski, J.M.; Wolf, W.M.; Ochocki, J. Synthesis, Characterization, and Antimicrobial Activity of Silver(I) and Copper (II) Complexes of Phosphate Derivatives of Pyridine and Benzimidazole. Chem. Med. Chem. 2014, 9, 169-176. [CrossRef] [PubMed]

6. Lu, M.; Yu, S.K.; Wang, Z.X.; Xin, Q.W.; Sun, T.; Chen, X.; Liu, Z.Y.; Chen, X.Y.; Weng, J.; Li, J.S. Zwitterionic choline phosphate functionalized chitosan with antibacterial property and superior water solubility. Eur. Polym. J. 2020, 134, 109821. [CrossRef]

7. Torsten, B.; Sorensen, M.H.; Poul, N.; Troels, K.; Claus, N.; Jesper, W. Synthesis and antiviral evaluation of novel conformationally locked nucleosides and masked 5'-phosphate derivatives thereof. J. Chem. Soc. 2002, 1, 1655-1662.

8. Pertusati, F.; Pileggi, E.; Richards, J.; Wootton, M.; Leemputte, T.V.; Persoons, L.; David, D.C.; Villanueva, X.; Daelemans, D.; Steenackers, H.; et al. Drug repurposing: Phosphate prodrugs of anticancer and antiviral FDA-approved nucleosides as novel antimicrobials. J. Antimicrob. Chemother. 2020, 75, 2864-2878. [CrossRef]

9. McGuigan, C.; Madela, K.; Aljarah, M.; Bourdin, C.; Arrica, M.; Barrett, E.; Jones, S.; Kolykhalov, A.; Bleiman, B.; Bryant, K.D.; et al. Phosphorodiamidates as a Promising New Phosphate Prodrug Motif for Antiviral Drug Discovery: Application to Anti-HCV Agents. J. Med. Chem. 2011, 54, 8632-8645. [CrossRef]

10. Cytlak, T.; Skibinska, M.; Kaczmarek, P.; Kaźmierczak, M.; Magdalena, R.; Kubicki, M.; Koroniak, H. Functionalization of $\alpha$-hydroxyphosphonates as a convenient route to $\mathrm{N}$-tosyl- $\alpha$-aminophosphonates. RSC Adv. 2018, 8, 11957-11974. [CrossRef]

11. Dussart, J.; Guedeney, N.; Deschamp, J.; Monteil, M.; Gager, O.; Legigan, T.; Migianu-Griffoni, E.; Lecouvey, M. A convenient synthetic route towards H-bisphosphinates. Org. Biomol. Chem. 2018, 16, 6969-6979. [CrossRef]

12. Kalla, R.M.N.; Zhang, Y.; Kim, I. Highly efficient green synthesis of $\alpha$-hydroxyphosphonates using a recyclable choline hydroxide catalyst. New J. Chem. 2017, 41, 5373-5379. [CrossRef]

13. Guerra, D.H.; Kennedy, A.R.; Leon, E.I.; Martín, Á.; Pérez-Martín,I.; Rodríguez, M.S.; Suárez, E. Synthetic Approaches to Phosphasugars (2-oxo-1,2-oxaphosphacyclanes) Using the Anomeric Alkoxyl Radical $\beta$-Fragmentation Reaction as the Key Step. J. Org. Chem. 2020, 85, 4861-4880. [CrossRef]

14. Bálint, E.; Tajti, Á.; Ladányi-Pára, K.; Tóthet, N.; Mátravölgyial, B.; Keglevich, G. Continuous flow synthesis of $\alpha$-aryl- $\alpha$-aminophosphonates. Pure Appl. Chem. 2019, 91, 67-76. [CrossRef] 
15. Vamisetti, G.B.; Chowdhury, R.; Ghosh, S.K. Organocatalytic decarboxylative aldol reaction of $\beta$-ketoacids with $\alpha$-ketophosphonates en route to the enantioselective synthesis of tertiary $\alpha$-hydroxyphosphonates. Org. Biomol. Chem. 2017, 15, 3869-3873. [CrossRef]

16. Kategaonkar, A.H.; Pokalwar, R.U.; Sonar, S.S.; Gawali, V.U.; Shingate, B.B.; Shingare, M.S. Synthesis, in vitro antibacterial and antifungal evaluations of new $\alpha$-hydroxyphosphonate and new $\alpha$-acetoxyphosphonate derivatives of tetrazolo [1, 5-a] quinoline. Eur. J. Med. Chem. 2010, 45, 1128-1132. [CrossRef]

17. Babu, Y.H.; Kumar, M.A.; Srinivasulu, K.; Reddy, C.S. Synthesis and antimicrobial activity of novel 2-(heteryl-carboxamido)-2,3-dihydro-1H-1,2,5-oxadiazolo[3,4-c] [1,3,2] diazaphosphole-2-oxides. Arkivoc 2006, 11, 189-197. [CrossRef]

18. Zuo, N.; He, H.W. Synthesis and Biological Activity of A-Hydroxyphosphonates. Phosphorus Sulfur Silicon Relat. Elem. 2008, 183, 621-622. [CrossRef]

19. David, E.; Cagnol, S.; Goujon, J.Y.; Egorov, M.; Taurelle, J.; Benesteau, C.; Morandeau, L.; Moal, C.; Sicard, M.; Pairel, S. 12b80-Hydroxybisphosphonate Linked Doxorubicin: Bone Targeted Strategy for Treatment of Osteosarcoma. Bioconj. Chem. 2019, 30, 1665-1676. [CrossRef]

20. Malwal, S.R.; Chen, L.; Hicks, H.; Qu, F.; Liu, W.D.; Shillo, A.; Law, W.X.; Zhang, J.N.; Chandnani, N.; Han, X.; et al. Discovery of Lipophilic Bisphosphonates That Target Bacterial Cell Wall and Quinone Biosynthesis. J. Med. Chem. 2019, 62, 2564-2581. [CrossRef]

21. Wang, L.; Yao, Z.G.; Xu, F.; Shen, Q. Lanthanide amides [(Me 3 Si) 2N] 3Ln( $\mu$-Cl) Li (THF)3-catalyzed phospho-aldol-Brook rearrangement reaction of dialkyl phosphites with isatins. Heteroat. Chem. 2012, 23, 449-456. [CrossRef]

22. Gangaram, P.; Ranga, S.; Subhas, G.; Manab, C. BuLi-triggered phospha-Brook rearrangement: Efficient synthesis of organophosphates from ketones and aldehydes. Tetrahedron Lett. 2015, 56, 3796-3798.

23. Peng, L.; Wang, L.L.; Bai, J.F.; Jia, L.N.; Yang, Q.C.; Huang, Q.C.; Xu, X.Y.; Wang, L.X. Corrigendum to "Highly effective and enantioselective phospho-Aldol reaction of diphenyl phosphite with N-alkylated isatins catalyzed by quinine". Tetrahedron Lett. 2011, 52, 6207-6209. [CrossRef]

24. Spilling, C.D. New Aspects in Phosphorus Chemistry II. Topics in Current Chemistry, 223, edited by Jean-Pierre Majoral. J. Am. Chem. Soc. 2003, 125, 11453. [CrossRef]

25. Hayashi, M.; Nakamura, S. Catalytic Enantioselective Protonation of $\alpha$-Oxygenated Ester Enolates Prepared through Phospha-Brook Rearrangement. Angew. Chem. Int. Ed. 2011, 50, 2249-2252. [CrossRef]

26. Kondoha, A.; Terada, M. Brønsted base-catalyzed $\alpha$-oxygenation of carbonyl compounds utilizing the [1,2]-phospha-Brook rearrangement. Org. Chem. Front. 2015, 2, 801-805. [CrossRef]

27. Kumaraswamy, S.; Selvi, R.S.; Kumaraswamy, K.C. Synthesis of New $\alpha$-Hydroxy-, $\alpha$-Halogeno- and Vinylphosphonates Derived from 5,5-Dimethyl-1,3,2-dioxaphosphinan-2-one. Synthesis 1997, 2, $207-212$. [CrossRef]

28. Kuroboshi, M.; Ishihara, T.; Ando, T. Reaction of fluorinated ketones with dialkyl phosphites: An efficient and selective transformation of aryl F-alkyl ketones into dialkyl aryl (F-alkyl) methyl phosphates. J. Fluor. Chem. 1988, 39, 293-298. [CrossRef]

29. Gancarz, R.; Gancarz, I.; Walkowiak, U. On the Reversibility of Hydroxyphosphonate formation in the kabachnik-fields reaction. Phosphorus Sulfur Silicon Relat. Elem. 1995, 104, 45-52. [CrossRef]

30. Sun, Y.M.; Xin, N.; Xu, Z.Y.; Liu, L.J.; Meng, F.J.; Zhang, H.; Fu, B.C.; Liang, Q.J.; Zheng, H.X.; Sun, L.J.; et al. Addition of optically pure H-phosphinate to ketones: Selectivity, stereochemistry and mechanism. Org. Biomol. Chem. 2014, 12, 9457-9465. [CrossRef]

31. Timmler, H.; Kurz, J. Zur Bildung von Phosphorsäureestern und $\alpha$-Hydroxy-phosphonsäureestern bei der Umsetzung von Dialkylphosphiten mit aromatischen Ketonen. Chem. Ber. 1971, 104, 3740-3749. [CrossRef]

32. Kondoh, A.; Terada, M. Brønsted Base Catalyzed [2,3]-Wittig/Phospha-Brook Tandem Rearrangement Sequence. Org. Lett. 2013, 15, 4568-4571. [CrossRef]

33. Kondoh, A.; Aita, K.; Ishikawa, S.; Terada, M. Synthesis of Tetrasubstituted Furans through One-Pot Formal [3 + 2] Cycloaddition Utilizing [1,2]-Phospha-Brook Rearrangement. Org. Lett. 2020, 22, 2105-2110. [CrossRef] [PubMed]

34. Avila-Ortiz, C.G.; Juaristi, E. Novel Methodologies for Chemical Activation in Organic Synthesis under Solvent-Free Reaction Conditions. Molecules 2020, 25, 3579. [CrossRef] [PubMed] 
35. Sarkar, A.; Santra, S.; Kundu, S.K.; Hajra, A.; Zyryanov, G.V.; Chupakhin, O.N.; Charushin, V.N.; Majee, A. A decade update on solvent and catalyst-free neat organic reactions: A step forward towards sustainability. Green Chem. 2016, 18, 4475-4525. [CrossRef]

36. Zangade, S.; Patil, P.A. Review on Solvent-Free Methods in Organic Synthesis. Curr. Org. Chem. 2019, 23, $2295-2318$. [CrossRef]

37. Xu, F.Z.; Wang, Y.Y.; Xun, X.W.; Huang, Y.; Jin, Z.C.; Song, B.A.; Wu, J. Diverse Oxidative C(sp2)-N Bond Cleavages of Aromatic Fused Imidazoles for Synthesis of $\alpha$-Ketoamides and N-(pyridin-2-yl) arylamides. J. Org. Chem. 2019, 84, 8411-8422. [CrossRef]

38. Trogler, W.C.; Stewart, R.C.; Marzilli, L.G. Trans effect of the good .sigma. donor ligands dimethyl phosphate, methyl phenyl phosphonate, and diphenylphosphinate. Evidence for complete bond breaking in the transition state of SN1lim reactions of dimethylphosphonatocobaloxime and methylcobaloxime complexes. J. Am. Chem. Soc. 1974, 96, 3697-3699.

39. Firoozpour, L.; Gao, L.X.; Moghimi, S.; Parvin, P.; Jamshid, D.; Wang, M.W.; Zahra, R.; Dadgar, A.; Yahyavi, H.; Amanlou, M.; et al. Efficient synthesis, biological evaluation, and docking study of isatin based derivatives as caspase inhibitors. Enzyme Inhib. Med. Chem. 2020, 35, 1674-1684. [CrossRef]

40. Joshi, D.B. To synthesize, characterization and pharmacological evaluation of novel substituted Isatin derivatives. J. Biomed. Pharm. Res. 2020, 9, 51-60. [CrossRef]

41. Guo, H.; Diao, Q.P. The Anti-Breast Cancer Potential of Bis-Isatin Scaffolds. Curr. Top. Med. Chem. 2020, 20, 1499-1503. [CrossRef]

42. Lahari, K.; Raja, S. Design and synthesis of novel isatin derivatives as potent analgesic, anti-inflammatory and antimicrobial agents. J. Chem. Sci. 2020, 132, 94. [CrossRef]

43. Fang, W.; Liu, G.G.; Huang, X.F.; Jia, J.; Wang, X.W. Organic Base Catalyzed Cascade Phospho-Aldol-Brook Rearrangement Reaction of Isatins with H-phosphonates. Chin. J. Org. Chem. 2014, 34, 1177-1182. [CrossRef]

Publisher's Note: MDPI stays neutral with regard to jurisdictional claims in published maps and institutional affiliations.

(C) 2020 by the authors. Licensee MDPI, Basel, Switzerland. This article is an open access article distributed under the terms and conditions of the Creative Commons Attribution (CC BY) license (http://creativecommons.org/licenses/by/4.0/). 